\title{
Leukemia Inhibitory Factor Determines the Growth Status of Injured Adult Sensory Neurons
}

\author{
William B. J. Cafferty, ${ }^{1}$ Natalie J. Gardiner, ${ }^{1}$ Isabella Gavazzi, ${ }^{2}$ James Powell, ${ }^{1}$ Stephen B. McMahon, ${ }^{1}$ \\ John K. Heath, ${ }^{3}$ John Munson, ${ }^{4}$ James Cohen, ${ }^{2}$ and Stephen W. N. Thompson ${ }^{1}$ \\ ${ }^{1}$ Centre for Neuroscience Research and 2Medical Research Council Centre for Developmental Neurobiology, Guy's, \\ King's, and St. Thomas' School of Biomedical Science, King's College London, London SE1 1UL, United Kingdom, \\ ${ }^{3}$ School of Biosciences, University of Birmingham, Birmingham B15 2TT, United Kingdom, and ${ }^{4}$ Department of \\ Neuroscience, University of Florida College of Medicine, Gainesville, Florida 32610
}

Conditioning injury to adult mammalian sensory neurons enhances their regeneration potential. Here we show that leukemia inhibitory factor (LIF) is a fundamental component of the conditioning response. Conditioning injury in vivo significantly increases the intrinsic growth capacity of sensory neurons in vitro from LIF+/+ mice. This conditioning effect is significantly blunted in sensory neurons from LIF-/- mice. Enhanced growth is rescued in vitro in LIF-/- mice by the addition of exogenous LIF, and the effect blocked by human LIF-05, an LIF receptor antagonist. Furthermore, we demonstrate that LIF promotes elongating but not arborizing neurite outgrowth in vitro and is required for normal regeneration of injured adult sensory neurons in vivo. LIF is also functionally protective to peptidergic sensory neurons after nerve damage in vivo. Our results indicate that the alteration in intrinsic growth status of injured sensory neurons depends, at least in part, on LIF.

Key words: leukemia inhibitory factor; gp130; regeneration; conditioning lesion; axotomy; sensory neuron
The regenerative capacity of sensory neurons is determined by their intrinsic growth status and access to a permissive growth substrate. An increase in the intrinsic growth status of adult sensory neurons can be achieved by delivering a conditioning lesion to peripheral nerves (McQuarrie and Grafstein, 1973; McQuarrie et al., 1977). Such conditioning lesions increase the ability of adult dorsal root ganglion (DRG) neurons to successfully regenerate into peripheral nerves (Carlson, 1983), nerve grafts (McQuarrie and Grafstein, 1973; Carlson, 1983; Richardson and Issa, 1984; Sjoberg and Kanje, 1990; Chong et al., 1996) across the dorsal root entry zone into the spinal cord (Richardson and Verge, 1987), and within spinal tracts (Neumann and Woolf, 1999). The increase in intrinsic growth status can also be detected in vitro as an earlier, and enhanced, rate of neurite elongation in dissociated adult DRG neurons or explants after previous conditioning injury in vivo (Hu-Tsai et al., 1994; Edstrom et al., 1996; Smith and Skene, 1997).

Successful regeneration requires that neurons survive and initiate rapid and directed neurite outgrowth. Damaged adult DRG neurons survive and mount a two-phase regenerative response. Within the first $48 \mathrm{hr}$ in vitro, adult sensory neurons have a constitutive capacity for short, highly arborized sprouting with limited linear extension (Smith and Skene, 1997). The second phase, commencing after a $48 \mathrm{hr}$ delay, is characterized by a dramatically enhanced neurite elongation with a reduction in

Received March 8, 2001; revised May 15, 2001; accepted May 31, 2001.

This work was supported by Action Research (United Kingdom) and by the Cancer Research Campaign (London) . I.G. is in receipt of a Wellcome Fellowship. W.B.J.C. is supported by the Biotechnology and Biological Sciences Research Council and GlaxoSmithKline. We thank Dr. M. S. Ramer for analysis suggestions and Dr. A. Vernallis for recombinant LIF and LIF-05 and K. Faulkner for expert maintenance of LIF-/- colony.

Correspondence should be addressed to Dr S. W. N. Thompson, Centre for Neuroscience Research, First Floor Hodgkin Building, Guy's Hospital, King's College London, London SE1 1UL, UK. E-mail: Stephen.W.Thompson@kcl.ac.uk. Copyright (C) 2001 Society for Neuroscience 0270-6474/01/217161-10\$15.00/0 neurite branching. This switch from arborizing to elongating growth is dependent on novel gene transcription (Smith and Skene,1997), which changes the intrinsic growth status of the injured neuron. Although recent work has shown that reexpression of growth cone proteins can enhance the growth capacity of injured spinal axons (Bomze et al., 2001), the factors responsible for altered growth states in adult regenerating DRG neurons remain largely unknown.

Several candidate molecules exist. Leukemia inhibitory factor (LIF) is the prototypic member of the gp130 family of cytokines that also includes interleukin-6, ciliary-derived neurotrophic factor, oncostatin $\mathrm{M}$, cardiotrophin-1, and cardiotrophin-likecytokine. LIF is absent from the adult mammalian nervous system but is upregulated by Schwann cells after injury (Banner and Patterson, 1994; Curtis et al., 1994; Dowsing et al., 1999), is retrogradely transported by, and accumulates within sensory neurons in the DRG (Thompson et al., 1997). Here it induces transcription-dependent changes that may underlie the ability of neurons to survive injury and promote regeneration. LIF is known to regulate the expression of galanin (Corness et al., 1996; Sun and Zigmond, 1996; Thompson et al., 1998), peripherin (Lecomte et al., 1998), and Reg-2 (Livesey et al., 1997). Furthermore, gp130 family members promote survival of embryonic motor and sensory neurons (Arce et al., 1999; Thier et al., 1999). LIF therefore fulfills several of the criteria required of a neurotrophic factor.

We have designed experiments to determine the effect of LIF on neurite growth of adult sensory neurons in vitro, to determine the effect of conditioning injuries on neurite outgrowth in the absence or presence of LIF signaling, and the ability of LIF to rescue the phenotype of damaged sensory neurons in vivo. We identify LIF as an injury-induced conditioning factor capable of mediating the elongation phase of sensory neuron regeneration in 
vitro, and therefore, is essential for normal regeneration of injured sensory neurons in vivo.

\section{MATERIALS AND METHODS}

Neuronal cultures. Adult homozygous LIF $-/-$ and LIF $+/+$ mice and 28-d-old male Wistar rats were used in this study. The strain of LIF knock-out (KO) mice used in this study was that of Steward et al. (1992) intermittently backcrossed to maintain viability [(C57BL6xBALB/C) $\times$ (CBA/CaxC57BL6J)]. Animals of either sex were used in all experiments because sexually dimorphic alterations within the sciatic nerve after injury have not been reported (Sugiura et al., 2000). The left sciatic nerve of LIF- - - and $+/+$ mice $(n=8)$ was axotomized at mid-thigh level, $14 \mathrm{~d}$ before culture. DRG cells were isolated from both rats and mice using identical techniques. Ganglia were removed from L4 and L5 spinal levels from anesthetized animals, cleared of connective tissue, and chemically dissociated in $0.125 \%$ collagenase for $1.5 \mathrm{hr}$ at $37^{\circ} \mathrm{C}$ in $5 \% \mathrm{CO}_{2}$. The ganglia were mechanically dissociated by gentle trituration in $1 \mathrm{ml}$ of modified Bottenstein and Sato's medium (BS; serum free) in Ham's F-12 (Life Technologies, Gaithersburg, MD) then centrifuged through 15\% BSA at $600 \mathrm{rpm}$ for $6 \mathrm{~min}$. Dissociated neurons were resuspended in $\mathrm{Ca}^{2+}$ - and $\mathrm{Mg}^{2+}$-free HBSS (Life Technologies), containing $50 \mu \mathrm{g} / \mathrm{ml}$ DNase (type I; Sigma, Poole, UK) and $250 \mu \mathrm{g} / \mathrm{ml}$ soybean trypsin inhibitor (type II; Sigma) and diluted in BS to a final concentration of $1500-2500$ cells $/ \mathrm{ml}$. Cells were cultured under the following conditions. BS alone (control) or BS supplemented with one or more of the following factors: NGF (10 ng/ml), trkA-IgG (100 ng/ml; Genentech, San Francisco, CA), LIF (100 pg and $100 \mathrm{ng} / \mathrm{ml}$; a gift from A. Vernallis, University of Aston, UK), and recombinant human LIF (rhLIF)-05 (100 $\mathrm{ng} / \mathrm{ml}$, gift from A. Vernallis). Cells were plated onto Lab-Tek (Nunc, Fisher Scientific, Loughborough, UK) chamber slides coated with polyL-lysine $(2 \mathrm{mg} / \mathrm{ml}$; Sigma) and Englebreth-Holm-Swarm laminin (10 $\mu \mathrm{g} / \mathrm{ml}$; Sigma). Cultures were incubated for $18 \mathrm{hr}$ at $37^{\circ} \mathrm{C}$ in a humidified atmosphere containing $5 \% \mathrm{CO}_{2}$. Salient non-neuronal (Schwann) cells were identified by S100 immunoreactivity (data not shown). Schwann cells are present at very low density and were found not to associated with neurons of any phenotype regardless of culture conditions. The fact that neurons cultured in control media fail to extend neurites indicates the inability of these non-neuronal cells to influence growth responses over the culture time period in the present study.

Cell survival and viability assays. Cell counts were performed $18 \mathrm{hr}$ after plating to determine whether cells were being lost or becoming nonviable during incubation period. Total cell numbers per well were determined. To determine cell survival, a Trypan Blue exclusion assay was performed. Cells cultured under the above conditions were gently washed with warmed F-12 media and then incubated for $5 \mathrm{~min}$ in a $0.4 \%$ solution of Trypan Blue (Sigma). The cells were subsequently washed three times with F-12 before counting under a light microscope. Cells demonstrating dye uptake were classed as nonviable.

Immunohistochemistry. Cells were fixed with $4 \%$ ice-cold paraformaldehyde solution for $15 \mathrm{~min}$, then permeabilized with methanol at $-20^{\circ} \mathrm{C}$ for 3 min. Monoclonal antibodies against GAP-43 (1:1000; a gift G. Wilkin) or $\beta$ (III)tubulin (1:1000; Sigma) were used as pan neuronal markers. To identify specific neuronal subpopulations, antibodies against N52 (1:4000; Sigma), P2X 3 (1:500; a gift Roche Bioscience), or CGRP (1:8000; Sigma) were used. Cells were incubated with a combination of primary antibodies for $4 \mathrm{hr}$, then incubated for $1 \mathrm{hr}$ with appropriate Cy3- and FITC-conjugated secondary antibodies. All incubations were conducted at room temperature.

Four parameters of cell growth were assessed: percentage of neuritebearing neurons, neurochemical phenotype of neurite-bearing cells, length of longest neurite, and density of dendritic growth around the soma. Soma that extended neurites greater than two cell body diameters were classified as process-bearing neurons. Length of longest neurite and density of dendritic growth were measured from digitized images acquired from a CCD camera (model FA87; Grundig, UK) using a frame grabber (DT2876; Data Translation, Marlboro, MA) and quantified using an image analysis program (SigmaScan 4.01.003; SPSS, Chicago, IL). For measurements of dendritic density, neurite-bearing cells had their fluorescence set to a threshold, thereby eliminating variations in staining intensity. Over the dichrome image, two axes of uniform width were superimposed on opposite sides of the soma (random axis) extending along the entire neurite length. Average fluorescence intensity along each axis was plotted against distance. This provided a measure of mean fluorescence intensity (neurite density) in relation to distance from the cell body.
Animal surgery: mice. Anesthetized (sodium pentobarbital; $50 \mathrm{mg} / \mathrm{kg}$, i.p.) adult $\mathrm{LIF}+/+(n=4)$ and LIF- $-(n=6)$ mice of both sexes underwent a unilateral crush injury of the sciatic nerve at midthigh level. The nerve was crushed with the tips of watchmakers forceps protected by a SILASTIC cuff $(10 \mathrm{sec})$. Two days later the sciatic nerve was reexposed, and $0.2 \mu \mathrm{l}$ of $2 \%$ wheat germ agglutinin (WGA) was injected midpoint between the DRG and crush site. After $24 \mathrm{hr}$ animals were reanesthetized and transcardially perfused with heparinized saline followed by $4 \%$ paraformaldehyde. Ipsilateral sciatic nerves and L4 and L5 DRGs were removed, post-fixed for $2 \mathrm{hr}$, and cryoprotected overnight in $20 \%$ sucrose at $4^{\circ} \mathrm{C}$. Longitudinal sections of frozen sciatic nerve (30$\mu \mathrm{m}$-thick) were cut and thaw mounted. Double immunostaining was performed using anti-GAP-43 (1:2000) and anti-WGA $(20 \mu \mathrm{g} / \mathrm{ml}$; Vector Laboratories, UK). Sections were incubated with primary antibodies overnight at $4^{\circ} \mathrm{C}$, then incubated with appropriate tetramethyl rhodamine isothiocyanate (TRITC)- and FITC-conjugated secondary antibodies (1:100; Jackson ImmunoResearch, West Grove, PA) for $1 \mathrm{hr}$ at room temperature. Nerve sections were visualized and acquired from a CCD camera (Hamamatsu, Tokyo, Japan) using a frame grabber (DT2876; Data Translation, Marlboro, MA). Digital images were quantified using an image analysis program (SigmaScan 4.01.003; SPSS).

Animal surgery: rats. Adult male Wistar rats (200-250 gm) underwent unilateral axotomy of either sciatic or tibial nerves combined with intrathecal infusion of either vehicle (saline) or LIF. Peripheral nerves were exposed under sodium pentobarbital $(50 \mathrm{mg} / \mathrm{kg}$, i.p.) anesthesia and ligated at midthigh level. Concurrently a small laminectomy was performed at T11/T12, and a SILASTIC tube $(0.6 \mathrm{~mm}$ outer diameter) was inserted intrathecally so that its tip lay approximately adjacent to the $\mathrm{L} 2 / 3$ of the DRG. Its exterior end was attached to an osmotic minipump (type 2002; mean pumping rate, $0.55 \mu \mathrm{l} / \mathrm{hr}$; Alzet; Alza, Palo Alto, CA) filled with either saline $(n=11)$ or $\operatorname{rhLIF}(0.33 \mathrm{mg} / \mathrm{ml} ; n=7)$. Electrophysiological analysis was performed on three groups of animals: a naive group $(n=4)$ in which the tibial nerve was intact with an intrathecal cannula infusing saline, a group in which the tibial nerve was cut 2 weeks earlier with an intrathecal cannula infusing saline $(n=4)$, and a group with tibial nerve axotomy and an intrathecal cannula infusing rhLIF (3.96 $\mu \mathrm{g} / \mathrm{d} ; n=4)$. Immunohistochemical analysis of CRGP-IR was performed on two groups of animals: a group in which the sciatic nerve was cut with an intrathecal cannula infusing saline $(n=3)$ and a group with sciatic nerve axotomy and an intrathecal cannula infusing rhLIF $(3.96 \mu \mathrm{g} / \mathrm{d} ; n=3)$. Two weeks after axotomy animals were perfused with $4 \%$ paraformaldehyde as previously described. Ipsilateral and contralateral L4 and L5 DRGs were removed, post-fixed for $2 \mathrm{hr}$, and cryoprotected overnight at $4^{\circ} \mathrm{C}$ in $20 \%$ sucrose. Serial sections of frozen DRG were cut at a thickness of $15 \mu \mathrm{m}$ and mounted onto slides. Sections were incubated with anti-CGRP (1:4000; Affiniti) then TRITC-conjugated anti-rabbit IgG (1:200; Jackson ImmunoResearch).

\section{RESULTS}

\section{LIF does not initiate neurite growth in DRG cultures}

First, we have examined the components of neurite outgrowth in cultures of adult rat DRG neurons. The appearance of adult rat DRG cultures has been previously well described (Lindsay, 1988; Hu-Tsai et al., 1994). Acutely dissociated adult mammalian sensory neurons survive in vitro in the absence of serum or exogenous growth factors (Lindsay, 1988; Mulderry, 1994; Gavazzi et al., 1999) for periods of up to 2.5 months (Sosa et al., 1998). Using a Trypan blue exclusion cell viability assay, we also show that after $18 \mathrm{hr}$ in vitro in serum-free cultures, the vast majority of neurons are viable at this time point (Table 1). Regardless of culture conditions, there was no significant difference in the percentage of neurons displaying dye uptake (Table 1). Terminal deoxynucleotidyl transferase-mediated biotinylated UTP nick end labeling staining of cell cultures also failed to demonstrate significant cell death after $18 \mathrm{hr}$ in culture in any culture condition (data not shown).

After an initial quiescent period of $24 \mathrm{hr}$, adult sensory neurons initiate neurite outgrowth (Smith and Skene, 1997). We have used this window of quiescence to assess the growth-promoting activity of exogenous LIF. The addition of exogenous LIF alone (1 pg 
Table 1. Cell survival and viability data for sensory neurons isolated from adult rats, LIF+/+, and LIF-/- mice cultured for 18 hr in the presence or absence of trophic factors

\begin{tabular}{|c|c|c|c|c|c|c|c|}
\hline & \multicolumn{3}{|c|}{ Cell survival (mean number of cells/well \pm SEM) } & \multicolumn{4}{|c|}{ Cell viability (Trypan blue exclusion assay, $\%$ of cells with dye \pm SEM) } \\
\hline & $\begin{array}{l}\text { Control } \\
\text { (no LIF) }\end{array}$ & $\begin{array}{l}\text { LIF } \\
(100 \mathrm{ng} / \mathrm{ml})\end{array}$ & $\begin{array}{l}\text { NGF } \\
(10 \mathrm{ng} / \mathrm{ml})\end{array}$ & $\begin{array}{l}\text { Control } \\
\text { (no LIF) }\end{array}$ & $\begin{array}{l}\text { LIF } \\
(100 \mathrm{ng} / \mathrm{ml})\end{array}$ & $\begin{array}{l}\text { NGF } \\
(10 \mathrm{ng} / \mathrm{ml})\end{array}$ & $\mathrm{NGF} / \mathrm{LIF}$ \\
\hline Rat & $110 \pm 13$ & $97 \pm 16$ & $83 \pm 7$ & $0.06 \pm 0.01$ & $0.08 \pm 0.01$ & $0.08 \pm 0.01$ & $0.07 \pm 0.01$ \\
\hline $\mathrm{LIF}+/-$ & $183 \pm 10$ & $158 \pm 18$ & $184 \pm 6$ & $2.7 \pm 1$ & $1.35 \pm 0.5$ & $1.0 \pm 0.5$ & \\
\hline $\mathrm{LIF}-/-$ & $172 \pm 23$ & $185 \pm 9$ & $108 \pm 9$ & $2.2 \pm 0.3$ & $1.6 \pm 0.6$ & $3.7 \pm 0.5$ & \\
\hline
\end{tabular}

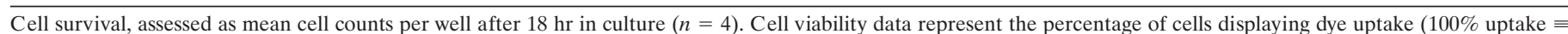

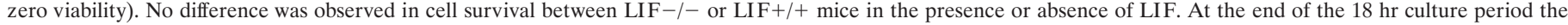
vast majority of neurons also remained viable, as evidenced by the high level of Trypan blue exclusion in all culture conditions.
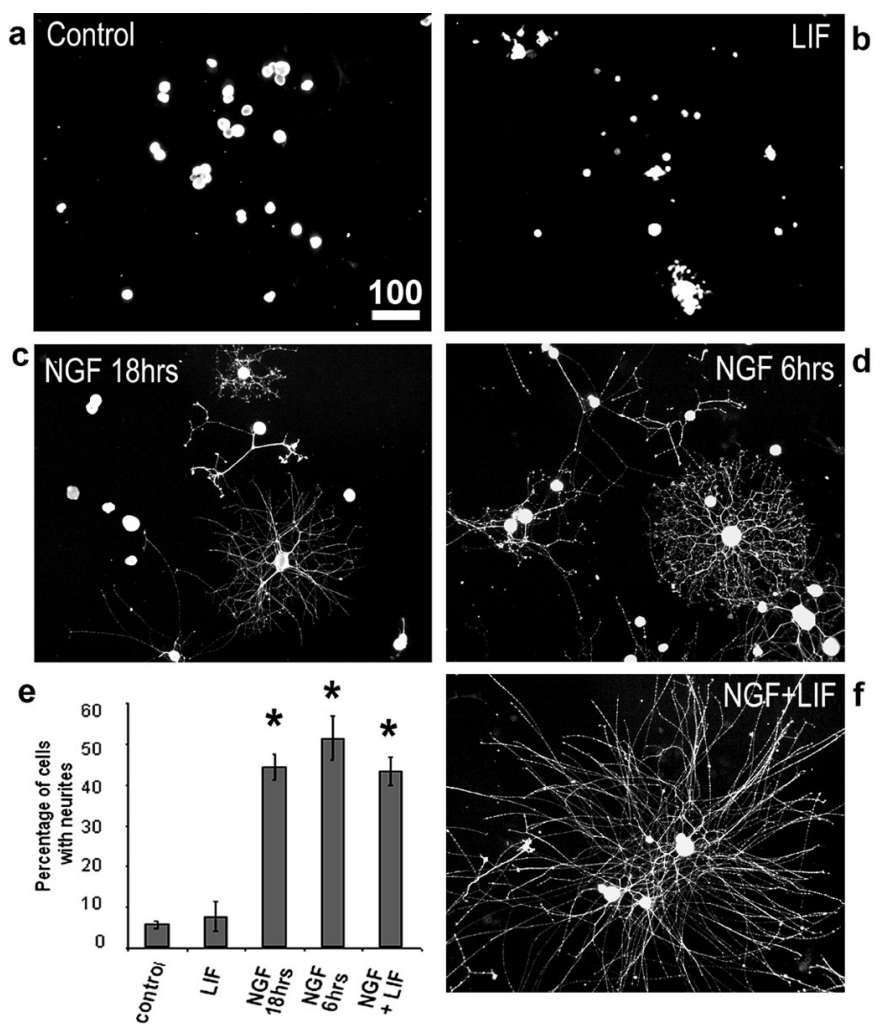

Figure 1. LIF does not initiate neuronal sprouting or influence the population of rat sensory neurons that respond to NGF. Dark-field photomicrographs of cultured adult sensory neurons showing immunofluorescence for $\beta$ (III)tubulin. $a$, Naive, adult rat sensory neurons in serumfree conditions and absence of trophic factors do not sprout within the 18 hr culture period. $b$, LIF alone $(100 \mathrm{pg} / \mathrm{ml})$ did not initiate growth after $18 \mathrm{hr}$ in culture. $c, d$, NGF $(10 \mathrm{ng} / \mathrm{ml})$, for either the entire culture period $(18 \mathrm{hr})$ or the first $6 \mathrm{hr}$ only, significantly increased the percentage of neurite-bearing sensory neurons when assessed at the $18 \mathrm{hr}$ time point $(p<0.05$; ANOVA). There was no significant difference in the percentage of neurite-bearing sensory neurons after $18 \mathrm{hr}$ exposure to NGF compared with $6 \mathrm{hr}$ exposure (e). There was no further significant change in the percentage of neurite-bearing sensory neurons in the presence of NGF (10 ng/ml; $18 \mathrm{hr})$ plus LIF (100 pg/ml; $18 \mathrm{hr})(e, f)$.

to $100 \mathrm{ng} / \mathrm{ml} ; 18 \mathrm{hr}$ ) failed to alter the percentage of neurons extending neurites compared with control medium $(7.7 \pm 3.6$ vs $5.6 \pm 0.8 \%$, respectively) (Figs. $1 B, 2 E)$. In contrast, NGF (10 $\mathrm{ng} / \mathrm{ml} ; 6$ and $18 \mathrm{hr}$ ) initiated neurite outgrowth in $44.3 \pm 3.3 \%$ of cells (Fig. $1 C-E$ ). The addition of LIF (1 pg to $100 \mathrm{ng} / \mathrm{ml}$ ) in combination with NGF (10 ng/ml) did not significantly alter the percentage of neurite-bearing cells when compared with the effects of NGF alone $(43.3 \pm 3.4 \%)$ (Fig. $1 E, F)$. LIF was there- fore unable to influence the percentage of neurite-bearing cells either alone or in combination with NGF.

\section{LIF induces neurite elongation in NGF-primed cells}

Despite the inability of LIF to initiate arborization, LIF dramatically restructured neurite morphology of NGF-primed sensory neurons. In the presence of NGF alone (10 ng/ml; $18 \mathrm{hr})$, a dense neuritic halo extended from the cell bodies (mean radius, $249 \pm$ $25 \mu \mathrm{m} ; n=42$ ) (Fig. $2 A, C$ ). The addition of LIF (1 pg to 100 $\mathrm{ng} / \mathrm{ml} ; 12 \mathrm{hr})$ to cells exposed to NGF $(10 \mathrm{ng} / \mathrm{ml})$ resulted in dramatic neurite restructuring. Neurite length was significantly enhanced compared with the effect of NGF alone (mean radius, $428 \pm 13 \mu \mathrm{m} ; n=30$ ) (Fig. $2 B, C$ ). We have demonstrated that LIF-induced elongation does not require the continued presence of NGF, because inclusion of the NGF sequestering antibody trkA-IgG (100 ng/ml; $12 \mathrm{hr}$ ) after an initial priming period (NGF $10 \mathrm{ng} / \mathrm{ml} ; 6 \mathrm{hr}$ ) did not prevent the enhanced neurite elongation. Neurite elongation was however inhibited by rhLIF05 (100 ng/ $\mathrm{ml}$ ), resulting in a morphology similar to that observed with NGF alone $(10 \mathrm{ng} / \mathrm{ml} ; 161 \pm 9$ vs $249 \pm 24 \mu \mathrm{m} ; n=42)$ (Fig. $2 C)$, confirming LIF, and not NGF, to be a neurite-elongation factor. Mean neurite density was assessed in each treatment group. There was a significant difference in the distance at which neurite density fell to $50 \%$ of its maximum value between neurons treated with NGF alone $(113 \pm 10 \mu \mathrm{m} ; n=10)$ and those supplemented with NGF plus LIF $(69 \pm 15 \mu \mathrm{m} ; n=10$; ANOVA) (Fig. 2D).

\section{Neurochemical phenotype of sprouting DRG neurons in vitro}

Polyclonal antibodies against the sensory neuropeptide CGRP (Fig. $3 A$ ), the purinoreceptor $\mathrm{P} 2 \mathrm{X}_{3}$ (Fig. $3 B$ ), and the heavy chain neurofilament protein N52 (Fig. $3 C$ ) were used as markers for nonpeptidergic small-diameter, peptidergic small-diameter, and large-diameter cells, respectively, to specifically identify three main groups of neurochemically distinct neurons within the DRG. Figure $3 D$ shows the percentage of neurite-bearing cells expressing each marker. In the presence of NGF alone $(10 \mathrm{ng} / \mathrm{ml}$; $18 \mathrm{hr}) 65 \pm 8 \%$ of neurite-bearing cells were CGRP-IR. In the presence of NGF plus LIF ( 6 hr NGF +12 hr LIF), $69 \pm 2 \%$ of neurite-bearing cells were CGRP-IR. In contrast, the percentage of neurite-bearing cells that were $\mathrm{P} 2 \mathrm{X}_{3}$-IR or N52-IR after exposure to NGF or NGF plus LIF was very low (12 \pm 1 and $4 \pm$ $1 \%$, respectively) (Fig. $3 D$ ). The effect of LIF on neurite elongation is therefore confined to small-diameter sensory neurons that express the sensory neuropeptide CGRP, respond to NGF, and are considered to be nociceptive in function. 
Figure 2. LIF induces neurite elongation in NGFprimed cells. Dark-field photomicrographs of cultured adult sensory neurons showing immunofluorescence for $\beta($ III)tubulin. $a$, Rat DRG neurons exposed to NGF alone $(10 \mathrm{ng} / \mathrm{ml})$ for $18 \mathrm{hr}$ display characteristically dense neurite outgrowth. Neurons exposed to NGF alone for $6 \mathrm{hr}$ also display the same characteristic outgrowth with no significant difference in mean neurite radius. $b$, DRG neurons grown in NGF (10 $\mathrm{ng} / \mathrm{ml})$ for $6 \mathrm{hr}$ and then exposed to LIF $(100 \mathrm{pg} / \mathrm{ml})$ for the remaining period of culture showed a dramatic change in neurite morphology and significant increase in neurite length at $18 \mathrm{hr}$ compared with the effect of NGF alone. $c$, Graph shows mean neurite length after $18 \mathrm{hr}$ in the presence of NGF $(10 \mathrm{ng} / \mathrm{ml})$, NGF $(10$ $\mathrm{ng} / \mathrm{ml})$ plus LIF $(100 \mathrm{pg} / \mathrm{ml})$, and NGF $(10 \mathrm{ng} / \mathrm{ml})$ plus LIF (100 pg/ml) plus hLIF-05 (100 ng/ml). Neurite length after LIF supplementation was significantly increased compared with the effect of NGF alone ( ${ }^{*} p<0.01$; Student's $t$ test). This effect was prevented by hLIF-05. $d$, Plot of neurite density with respect to distance from cell body of cells treated with NGF (10 ng/ml), NGF (10 ng/ml) plus LIF (100 $\mathrm{pg} / \mathrm{ml})$, or NGF $(10 \mathrm{ng} / \mathrm{ml})$ plus LIF $(100 \mathrm{pg} / \mathrm{ml})$ plus hLIF-05 (100 ng/ml). There was a significant difference in the distance at which neurite density fell to half maximum value between NGF-treated groups and those treated with NGF plus LIF $(p<0.05$; ANOVA). The elongating effect of LIF was prevented by inclusion of hLIF-05. Arrows represent the distance at which mean density fell to zero in NGF plus LIFtreated group. Each curve represents mean values from 40 cells from a minimum of three cultures.

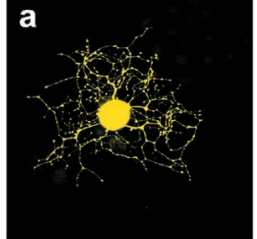

c
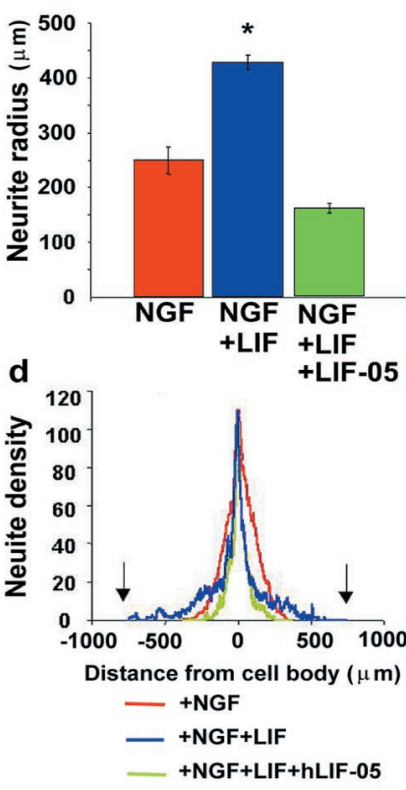

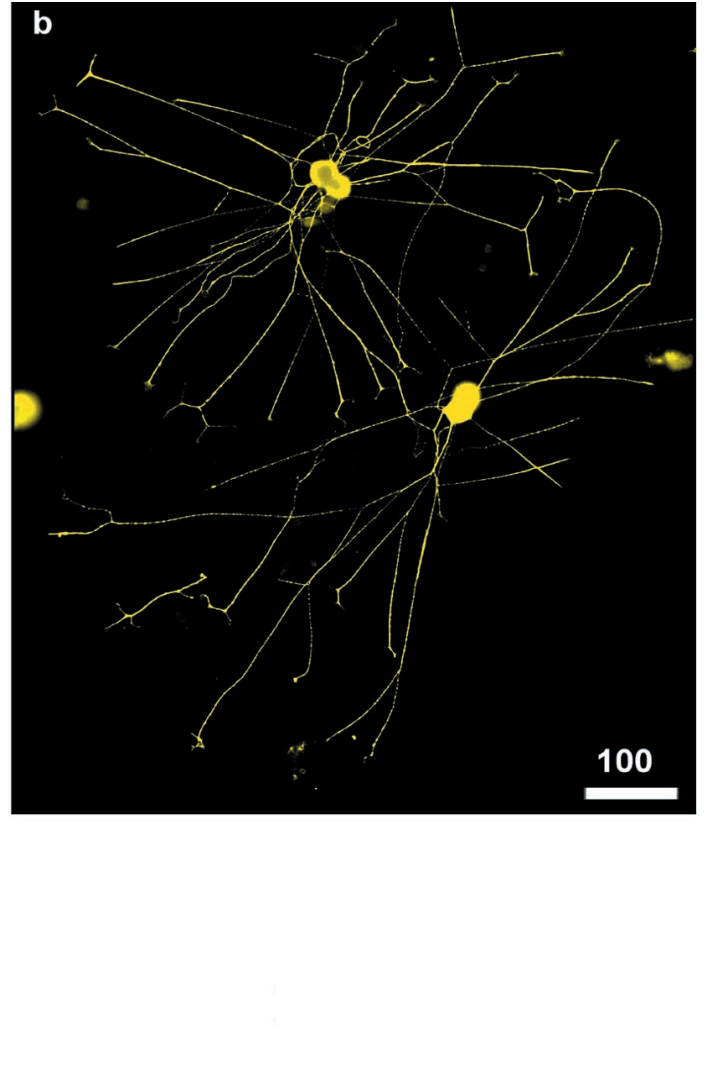

\section{The effect of conditioning nerve injuries is impaired in LIF knock-out mice}

Our data describing the effects of exogenous LIF suggests that this cytokine may be responsible for elongating neurite growth, a particular growth mode that is representative of an enhanced growth status. To assess whether LIF is responsible for the enhanced growth capacity of adult sensory neurons that follows a conditioning nerve injury, we compared the extent of neurite elongation after $18 \mathrm{hr}$ in culture between $\mathrm{LIF}+/+$ and LIF-/mice 2 weeks after a previous sciatic nerve axotomy in vivo. In the absence of trophic factors and in serum-free conditions, sensory neurons from naive (unconditioned) $\mathrm{LIF}+/+$ or $\mathrm{LIF}-/-\mathrm{DRG}$ failed to exhibit neurite outgrowth (Fig. $4 A, B, G$ ). In contrast, neurons from preconditioned LIF $+/+$ and LIF-/ - mice exhibited neurite outgrowth within this $18 \mathrm{hr}$ period (Fig. 4C,D,G). Neurite outgrowth from preconditioned LIF-/- sensory neurons, however, was significantly impaired in comparison to preconditioned LIF $+/+$ neurons $(793 \pm 122$ vs $1352 \pm 175 \mu \mathrm{m} ; n=$ 4 ; respectively) (Fig. $5 G)\left({ }^{*} p<0.05, t\right.$ test). The addition of LIF $(100 \mathrm{pg} / \mathrm{ml})$ to preconditioned LIF-/ - sensory neurons significantly rescued the impaired neurite elongation (preconditioned LIF-/-, $793 \pm 122 \mu \mathrm{m}$ vs preconditioned LIF-/- plus LIF, $1427 \pm 82 \mu \mathrm{m} ; \# p<0.05$ ) (Figs. $4 F, 5 G$ ). Restoration of neurite elongation was prevented by inclusion of rh-LIF05 (100 ng/ml) (749 $\pm 64 \mu \mathrm{m}$, data not shown). rhLIF05 is a synthetic LIF molecule that binds LIFR- $\beta$ in nonsignaling complexes (Vernallis et al., 1997). rh-LIF05 had no influence on neurite length of preconditioned LIF+/+ DRG neurons (data not shown) nor was there any further effect of LIF on neurite length in preconditioned LIF+/+ DRG cells (Fig. 4E, G).

Addition of NGF $(10 \mathrm{ng} / \mathrm{ml})$ partially mimicked the effect of a previous nerve lesion by inducing neurite arborization in naive
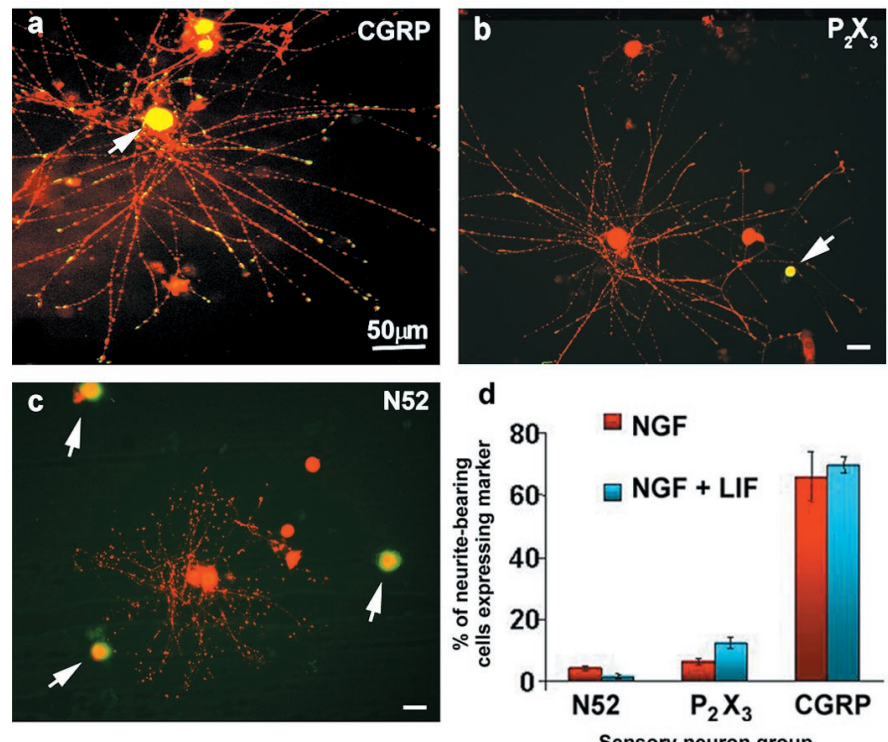

Figure 3. DRG neurons that extend neurites in the presence of NGF and LIF predominantly express CGRP. $a-c$, Dual immunofluorescence photomicrographs showing immunoreactivity for $\beta$-III tubulin (red) and CGRP $(a), \mathrm{P}_{2} \mathrm{X}_{3}(b)$, or N52 (c, green). Cells and dendrites expressing both markers appear yellow. Neurons have been cultured for $18 \mathrm{hr}$ in NGF plus LIF. $a$, A yellow cell body and neurites reveal costaining for both CGRP and neurite growth. $b$, Cells expressing P2X $\mathrm{X}_{3}$ and N52 (c) also express neurofilament and are therefore yellow. However, they do not display neurite growth. $d$, Graph showing the percentage of neuritebearing cells that are immunopositive for one of the three cell markers after supplementation with NGF alone or NGF plus LIF. The majority of neurons extending neurites in the presence of NGF plus LIF are immunoreactive for CGRP. 

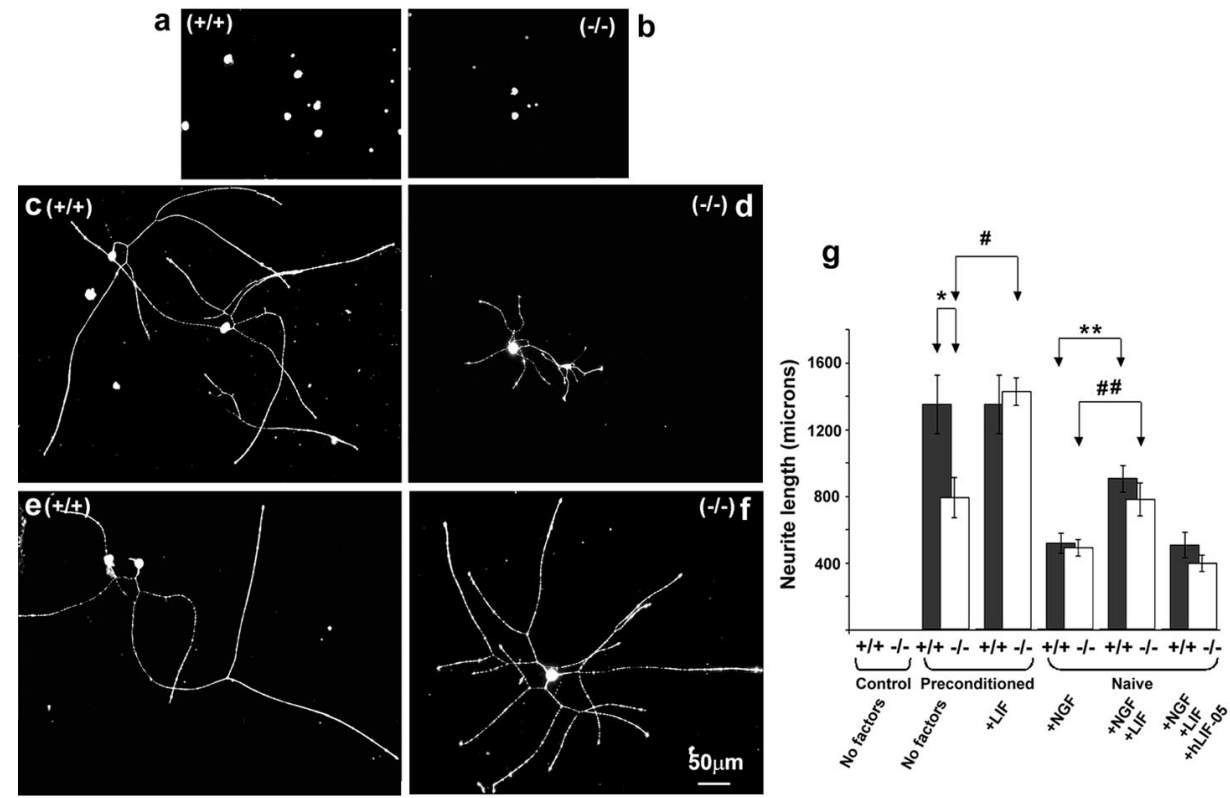

Figure 4. Enhanced, injury-induced neurite elongation is absent in LIF-/- mice. $a$, $b$, Naive, LIF $+/+$, and LIF-/- mouse adult sensory neurons in serum-free conditions and absence of trophic factors do not display growth responses within the $18 \mathrm{hr}$ culture period. $c$, Neurite elongation is significantly enhanced after $18 \mathrm{hr}$ in culture in DRG neurons from LIF+/+ mice subject to a conditioning sciatic axotomy 2 weeks before culture. $d$, Neurite elongation in cells from LIF-/- mice after conditioning sciatic injury is significantly reduced compared with wild-type growth. There was a significant difference between length of the longest neurite in $\mathrm{LIF}+/+$ and LIF $-/-$ mice under these conditions $(g$, no factors preconditioned $+/+$ vs no factors preconditioned $-/-; *{ }^{*} p<0.05 ; t$ test $)$. $f$, Addition of LIF $(100 \mathrm{pg} / \mathrm{ml})$ to neuronal cultures for $18 \mathrm{hr}$ restored the effect of preconditioning in LIF- - mice. Compared with the effect of conditioning alone, there was a significant increase in neuronal length $(g$; $-/-$ preconditioning no factors vs $-/-$ preconditioning plus LIF; \# $p<0.05 ; t$ test $). e$, g, Supplementation of LIF $(100 \mathrm{pg} / \mathrm{ml})$ to preconditioned LIF $+/+$ DRG neurons for $18 \mathrm{hr}$ did not further enhance neurite outgrowth. The effect of a previous nerve lesion was partially mimicked in naive DRG neurons from both LIF $+/+$ and LIF $-/-$ mice by the addition of NGF $(10 \mathrm{ng} / \mathrm{ml})$. Mean neurite length was lower, however, in both LIF $+/+$ and LIF $-/-$ mice $(518 \pm 60$ and $494 \pm 50 \mu \mathrm{m}$, respectively) compared with preconditioned sensory neurons from both genotypes $(g)$. Addition of NGF (10 ng $/ \mathrm{ml}) \mathrm{plus} \mathrm{LIF} \mathrm{(100} \mathrm{pg/ml)} \mathrm{to} \mathrm{naive} \mathrm{sensory}$ neurons further enhanced neurite elongation in both genotypes (LIF+/+ and LIF-/-; $906 \pm 79$ and $782 \pm 100 \mu \mathrm{m}$, respectively; $g$, \#\#, **), compared with the effect of NGF alone. However, addition of NGF plus LIF failed to fully recapitulate the effect of previous nerve injury on neurite elongation in either genotype.

DRG neurons from both $\mathrm{LIF}+/+$ and $\mathrm{LIF}-/-$ mice. Mean neurite length was lower however in $\mathrm{LIF}+/+$ and LIF $-/-$ mice (518 \pm 60 and $494 \pm 50 \mu \mathrm{m}$, respectively) (Fig. 4G) compared with preconditioned sensory neurons from both genotypes. Addition of NGF $(10 \mathrm{ng} / \mathrm{ml})$ plus LIF $(100 \mathrm{pg} / \mathrm{ml})$ significantly enhanced neurite elongation in both $\mathrm{LIF}+/+$ and $\mathrm{LIF}-/-$ mice (906 \pm 79 and $782 \pm 100 \mu \mathrm{m}$, respectively; \#\#, ** $p<0.05$ ) (Fig. $4 G)$, compared with the effect of NGF alone. Addition of NGF plus LIF however failed to totally recapitulate the effect of previous nerve injury on neurite elongation. The synergistic effect of LIF on neurite outgrowth was negated by rhLIF-05 $(100 \mathrm{ng} / \mathrm{ml})$ in both $\mathrm{LIF}+/+$ and $\mathrm{LIF}-/-$ mice $(508 \pm 76$ and $399 \pm 49 \mu \mathrm{m}$, respectively) (Fig. $4 G$ ). These results suggest that LIF promotes a distinct phase of neurite elongation that manifests as a change in growth status of sensory neurons observed after conditioning injury.

\section{Sensory neuron survival and viability in vitro is not impaired in LIF-/- mice}

Our data regarding the failure of neurite outgrowth after injury in LIF-/- mice may represent a lack of relative survival or viability of sensory neurons from these animals in vitro. To determine whether sensory neurons cultured from LIF $-/-$ mice survive as well as those from $\mathrm{LIF}+/+$ we have determined cell counts in $\mathrm{LIF}-/-$ and $\mathrm{LIF}+/+$ mice, in the presence or absence of LIF. We have also assayed cell viability in each group after $18 \mathrm{hr}$ with Trypan blue exclusion. After $18 \mathrm{hr}$ in culture, average LIF-/- sensory neuron counts were not significantly different between LIF-containing (100 nM) or LIF-excluding cultures (Table 1). Neither were these values significantly different from similar cultures from $\mathrm{LIF}+/+$ mice (Table 1). Trypan blue exclusion demonstrated equal viability across all genotype and culture conditions. Regardless of culture conditions there was no significant difference in the percentage of neurons displaying dye uptake (Table 1). These data indicate equal survival and viability of sensory neurons in LIF-/- and LIF $+/+$ mice and suggest that lack of neurite outgrowth is not attributable to these factors in $\mathrm{LIF}-/-$ mice.

\section{Peripheral nerve regeneration is impaired in LIF-/- mice in vivo}

We have further assessed the role of LIF in regeneration of injured peripheral axons in vivo. We have used WGA to determine the rate of sensory neuron regeneration across a crush injury to the sciatic nerve in $\mathrm{LIF}+/+$ and LIF $-/-$ mice. WGA is anterogradely and retrogradely transported predominantly by unmyelinated fibers (Swett and Woolf, 1985). Three days after injury WGA-IR fibers were visible proximal to the crush site in both $\mathrm{LIF}+/+$ and $\mathrm{LIF}-/-$ mice (Fig. $5 B, F$ ). In all $\mathrm{LIF}+/+$ mice the WGA-IR fibers penetrated through the crush site into the distal nerve stump (Fig. 5C). In contrast, in $\mathrm{LIF}-/-$ mice WGA-IR fibers failed to penetrate beyond the crush site (Fig. $5 H)$. WGA transport was unimpaired in $\mathrm{LIF}-/-$ mice because robust retrograde transport to the DRG was observed several 


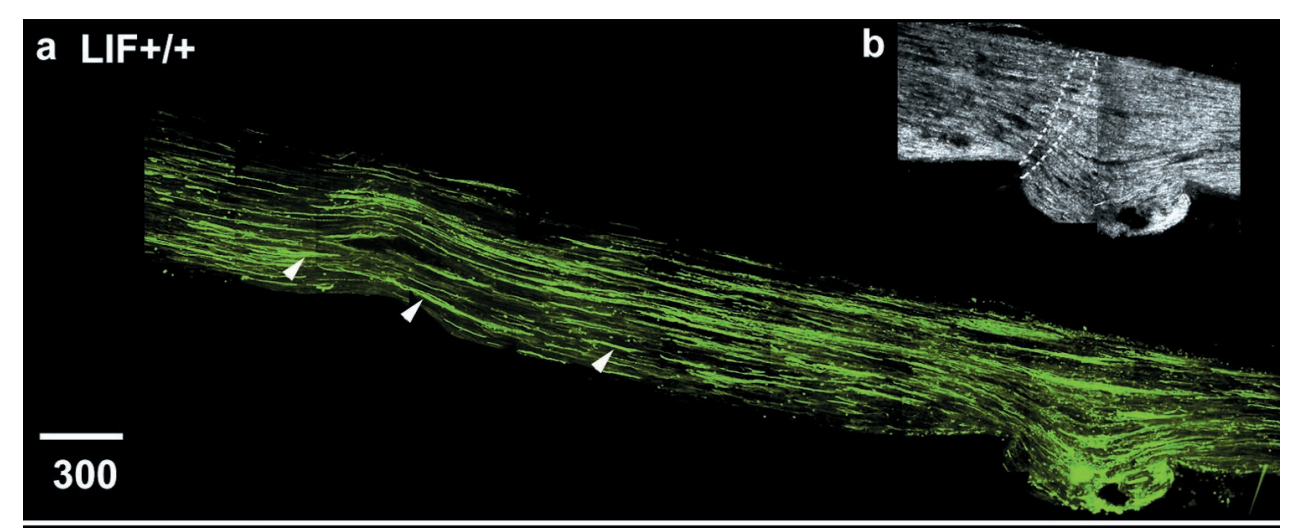

Figure 5. Peripheral nerve regeneration is retarded in LIF-/- mice in vivo. Immunofluorescence photomicrographs of sciatic nerves $3 \mathrm{~d}$ after complete nerve crush from $\mathrm{LIF}+/+(a-d)$ and LIF-/- $(e-h)$ mice. Site of nerve crush is indicated by dark-field inserts $(b, f)$ distal to the left. In $\mathrm{LIF}+/+$ mice, GAP-43 antibody reveals regenerating axons penetrating into the distal nerve segment $(a)$. A proportion of these fibers also display immunoreactivity for anterogradely transported WGA $(c)$. The ratio of distance achieved by WGA-transporting to GAP-43-IR fibers is close to unity. Arrowheads indicate double-labeled nerve fascicles. Retrograde transport of WGA to L5 DRG confirms that WGA-IR axons arise from small-diameter neuronal profiles $(d)$. GAP-43-IR fibers also penetrate into distal nerve segment in LIF-/- mice (e). In contrast to LIF+/+ mice, the growth of WGAtransporting fibers is significantly retarded in LIF-/- mice $(h)$. Arrowheads indicate WGA-IR fascicles. WGA-transport is unimpaired in LIF-/ - mice $(g)$. WGA-IR is detected within the L5 DRG, several millimeters proximal to the injection site. Examination of DRG sections also confirmed that WGA-transporting fibers in LIF-/mice also arise predominantly from smalldiameter neuronal profiles within the DRG.
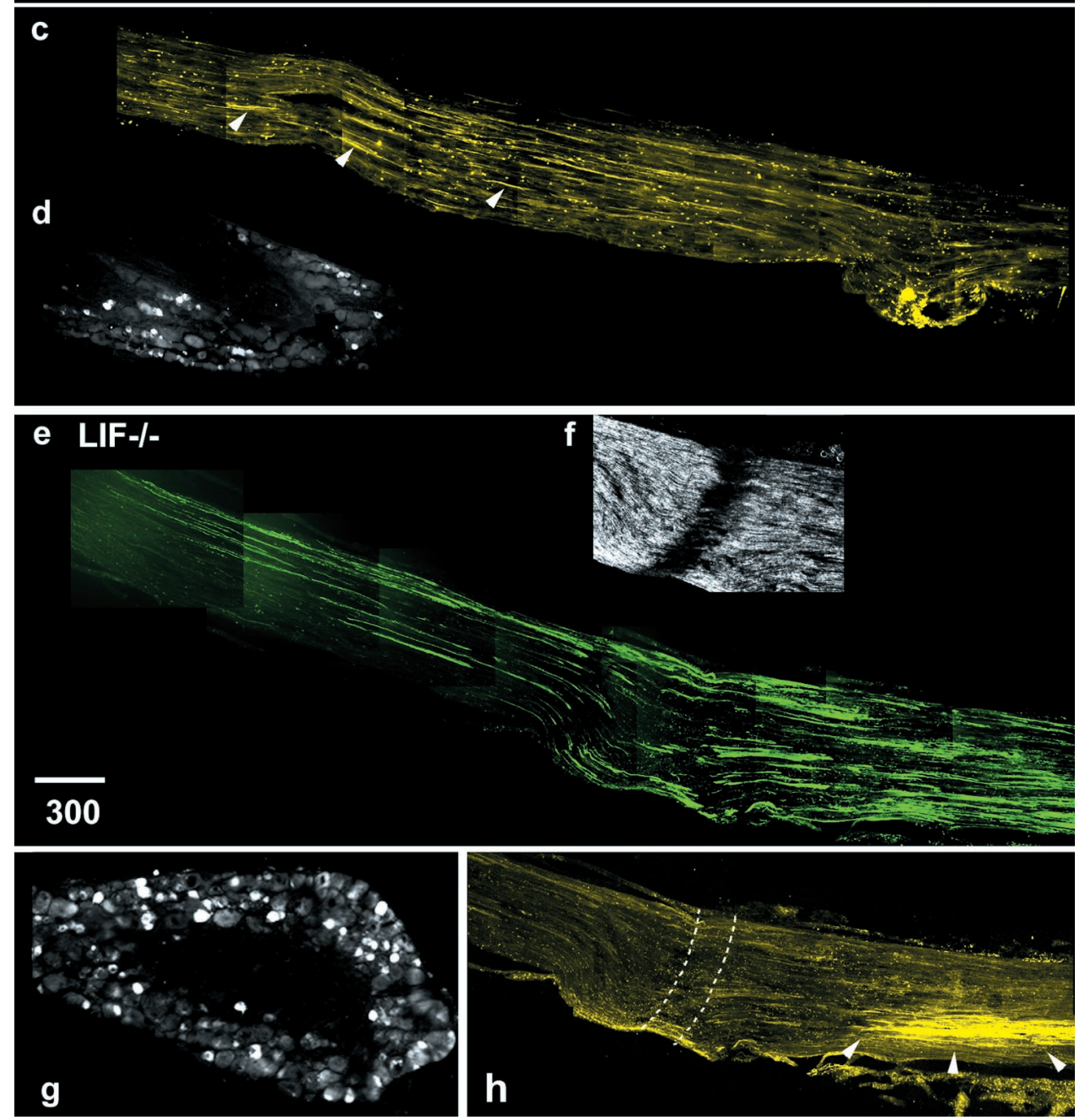

millimeters proximal to the injection site (Fig. $5 G$ ). Examination of DRG sections also confirmed that the regenerating fibers in these experiments arose predominantly from small-diameter profiles within the DRG (Fig. 5G). The regenerating peripheral nerve was co-stained with anti-GAP-43. GAP-43 is a developmentally regulated protein that is upregulated in all regenerating neurons. GAP-43-IR neurites were observed in both $\mathrm{LIF}+/+$ and $\mathrm{LIF}-/-$ mice penetrating through and beyond the crush site into the distal nerve stump (Fig. $5 A, E$ ). There was a significant difference in the ratio of distance achieved by WGA transporting to GAP-43-IR fibers in $\mathrm{LIF}+/+$ mice $(0.9 \pm 0.03 ; n=5)$ compared with LIF $-/-$ mice $(0.29 \pm 0.01 ; n=4)$. These data indicate that regeneration of WGA-transporting sensory neurons was significantly retarded in $\mathrm{LIF}-/-$ mice.

\section{LIF is protective for CGRP expressing C-fibers after adult rat sciatic nerve injury}

Finally we assessed the ability of exogenous LIF to ameliorate axotomy-induced changes in sensory neurons. LIF $(0.33 \mu \mathrm{g} / \mathrm{ml}$; $n=4)$ or saline vehicle $(n=4)$ was delivered intrathecally for 2 weeks after axotomy of the tibial nerve of adult Wistar rats. In intact animals, the conduction velocities (CVs) of myelinated fibers are uniformly distributed between 10 and $60 \mathrm{~m} / \mathrm{sec}$, and the $\mathrm{CVs}$ of unmyelinated fibers are distributed between 0.5 and 2.0 
a

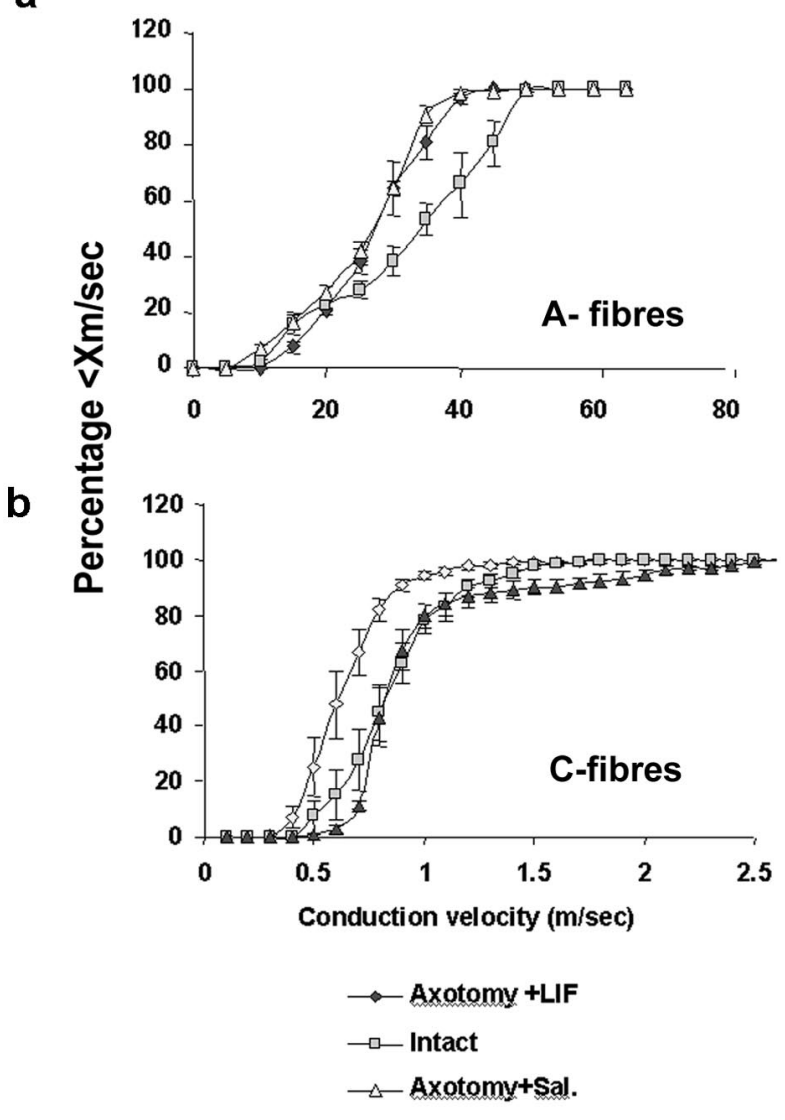

C

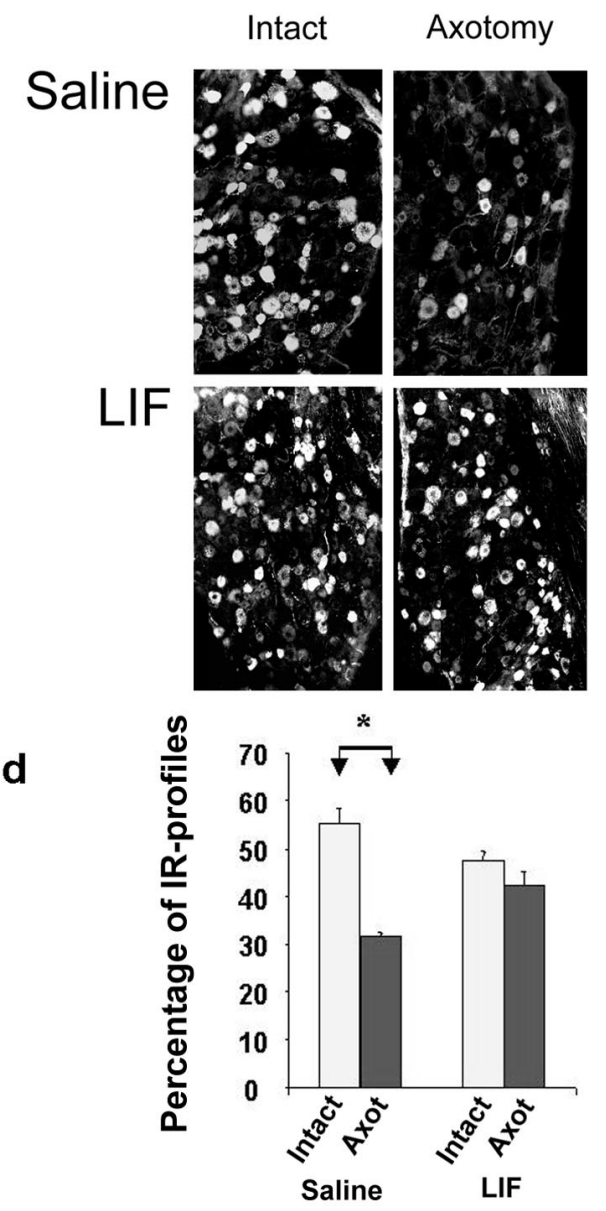

Figure 6. LIF is protective in vivo against injury-induced electrophysiological and neurochemical changes in DRG neurons. The CVs of A-fibers ( $a$ ) and C-fibers $(b)$ were measured by electrical stimulation of the axotomized peripheral nerve and recording and averaging electrical activity in strands of the L4 or L5 dorsal root. Animals were treated continuously for 2 weeks with intrathecal saline or LIF ( $0.33 \mu \mathrm{g} / \mathrm{ml}$ ). Cumulative sum (cusum) plots were constructed showing the average $\mathrm{CV}$ distributions from groups of three to five animals. Axotomy results in the slowing in conduction velocity of both fast conducting A-fibers $(a)$ and slowly conducting $\mathrm{C}$-fibers $(b)$ shown as a shift to the left of the cusum plots (Axotomy+Sal.). Intrathecal administration of LIF completely prevented the drop in C-fiber CVs, whereas it was completely ineffective in preventing the fall in A-fiber CVs after axotomy $($ Axotomy $+L I F)$. Axotomy also results in the loss of CGRP immunoreactivity from cell bodies within the DRG (c, Saline; intact vs $14 \mathrm{~d}$ axotomy). Continuous intrathecal administration of LIF completely prevented the loss of CGRP-IR from sensory neuron cell bodies within the DRG, $14 \mathrm{~d}$ after peripheral nerve injury. $d$, The percentage of CGRP-immunoreactive profiles within the L4 and L5 DRG was significantly different 2 weeks after nerve injury and after treatment with saline vehicle $\left({ }^{*} p<0.01 ; t\right.$ test; $\left.n=4\right)$. There was no significant difference in the percentage of CGRP-IR profiles 2 weeks after nerve injury in those animals treated continuously with intrathecal LIF compared with nerve-intact controls.

$\mathrm{m} / \mathrm{sec}$. These distributions are plotted as cumulative sum plots (Fig. 6A,B). After axotomy there is typically a decrease in CV because of alterations in ion channel and neurofilament expression. In axotomized animals treated with saline, both groups of sensory fibers showed significant decreases in CV (shown as a shift to the left; $p<0.05$; Kolmogorov-Smirnov; $n=4$ ) (Fig. $6 A, B)$. LIF did not prevent the decrease in the $\mathrm{CV}$ of the myelinated fibers (Fig. $6 A$ ) but completely prevented the reduction in CVs of the unmyelinated fibers $(p<0.05$ compared with vehicle-treated group; Kolmogorov-Smirnov; $n=4$ ) (Fig. $6 B$ ).

The expression of the sensory neuropeptide CGRP in the DRG was assessed 2 weeks after sciatic nerve axotomy and continuous intrathecal delivery of LIF or saline. Vehicle-treated animals displayed a significant decrease in the percentage of CGRP-IRpositive profiles compared with control uninjured ganglia (31 \pm $1 \%$ ipsilateral vs $55 \pm 3 \%$ contralateral; $n=3 ; p<0.05$; Students $t$ test) (Fig. $6 C, D$ ). In contrast, there was no significant difference between the percentage of CGRP-IR-positive profiles within axotomized ganglia in those animals treated with intrathecal LIF compared with contralateral uninjured DRGs (42 $\pm 3 \%$ ipsilateral vs $48 \pm 2 \%$ contralateral; $n=3 ; p<0.05$; unpaired $t$ test). Importantly, a significant difference was present between the percentage of CGRP-IR-positive profiles within saline-treated axotomy group compared with the LIF-treated axotomy group ( $31 \pm 0.5 \%$ saline group vs $42 \pm 3 \%$ LIF group; $n=3 ; p<0.05$; unpaired $t$ test). This effect of LIF was limited to the CGRPexpressing subpopulation of DRG neurons. Fluoride-resistant acid phosphatase (FRAP) is an enzyme present within nonpeptide-expressing sensory neurons and is depleted after axotomy. FR AP activity was depleted 2 weeks after peripheral nerve injury equally in both vehicle and LIF-treated animals $(24 \pm 2 \%$ ipsilateral vs $42 \pm 1 \%$ contralateral, vehicle-treated; $24 \pm 5 \%$ ipsilateral vs $46 \pm 1 \%$ contralateral, LIF-treated; data not shown). LIF is therefore able to rescue axotomy-induced functional and phenotypic changes within the peptidergic, unmyelinated sensory neurons. 


\section{DISCUSSION}

\section{LIF promotes a distinct "elongation" phase of axon growth in injured adult sensory neurons}

In the developing nervous system, LIF supports the survival of embryonic sympathetic, motor, and sensory neurons (Ernsberger et al., 1989; Martinou et al., 1992; Murphy et al., 1993, 1997; Cheema et al., 1994) In our current study it is important to distinguish this survival effect from true growth responses in our adult cultures in vitro. We have shown that the percentage of adult rat sensory neurons surviving and remaining viable after $18 \mathrm{hr}$ in vitro is identical in serum-free and LIF-treated cultures. We have also shown that there was no difference in the percentage of neurons expressing the markers CGRP, $\mathrm{P} 2 \mathrm{X}_{3}$, and N52 between culture conditions, suggesting that the three main groups of neurochemically distinct rat sensory neurons are present and approximate to the distribution found in vivo (Gavazzi et al., 1999). Furthermore, we have also shown that there is no impaired survival or lack of viability of sensory neurons grown from adult LIF-/- mice. Therefore, although studies have demonstrated that LIF may regulate sensory neuron survival in developing systems (Murphy et al., 1993, 1997), we suggest that our study with fully differentiated adult neurons represents true growthpromoting effects rather than survival or viability issues.

In the adult nervous system, distinct phases of axon growth are now considered to exist. When observed in vitro, two distinct modes of axon outgrowth have been described for adult sensory neurons. First, an arborizing neurite growth characterized by highly branched processes with limited linear extension. This is followed by an elongating regenerative growth phase (Smith and Skene, 1997). These differing forms of growth may have different trophic factor requirements. Our data confirm previous in vitro reports that initial neurite sprouting is neurotrophin-dependent (Mohiuddin et al., 1994; Gavazzi et al., 1999). Our data are also in line with evidence from in vivo studies illustrating that collateral branching of sensory neuron terminals, considered analogous to arborizing neurite growth in vitro, is dependent on NGF (Diamond et al., 1992a,b). Other factors are likely to be involved in long axon extension. Elegant studies using double knock-out mice for NGF/Bax or trkA/Bax, for example, suggest that extension of central processes of DRG axons into dorsal roots takes place in the absence of NGF signaling (Patel et al. 2000). In our study the elongating phase of neurite extension also continued in the absence of NGF signaling. Again this is consistent with work in vivo whereby, regenerative long-axon growth of injured peripheral neurons, considered analogous to elongating growth in vitro, is independent of NGF (Diamond et al., 1992a,b). This type of growth represents a switch to a rapid growth mode and depends on novel gene transcription (Smith and Skene, 1997). The notion of NGF-dependent and -independent components of neurite outgrowth is also supported from studies using long-term compartmentalized culture systems (Kimpinski et al., 1997). Under these circumstances the regrowth and arborization of severed neurites was strongly supported by NGF, however neurite extension into distal compartments proceeded in neurotrophin-free conditions. In our present experiments, neurite elongation continued in the presence of LIF and specific NGF sequestering antibodies supporting the notion that LIF was acting directly on sensory neurons and not via the production of NGF by neurons or nonneuronal cells. Although other possible regulators of sensory axon elongation and branching are known (e.g., Slit2; Wang et al., 1999), the present study has provided direct evidence that the injury-associated cytokine LIF may be responsible for this elongating phase of neurite extension. An effect of LIF on neuronal morphology has been observed in the sympathetic nervous system and within the CNS (Guo et al., 1997; Gadient et al., 1998, 1999).

\section{Conditioning-injury-induced growth is impaired in LIF-I- mice}

It has been known for many years that conditioning lesions enhance the regeneration of peripheral nerves (McQuarrie and Grafstein, 1973). To clinically exploit this response we clearly need to understand the mechanisms underlying the phenomenon. Conditioning injuries enhance growth by increasing the intrinsic growth status of the sensory neuron. Our study has shown that this increase in growth status is blunted in LIF-/- mice. Assuming the elongating phase of neurite growth in vitro represents such an augmented growth phase, then again we have data showing that LIF plays an important role in this neurite extension phase. By what process is injury to a peripheral nerve translated into enhanced growth status of the cell body? Damaged axons are exposed to wide range of positive and negative regulatory signals as they attempt regrowth. Exposure to this environment produces enhanced rates of neurite growth (Chong et al., 1996; Lankford et al., 1998; Sugiura et al., 2000). On the other hand, disruption of axon transport was shown to be adequate for enhanced elongating growth, albeit at a reduced level (Smith and Skene, 1997). Taken together with data presented in the present study, these studies suggest that a combination of reduced retrograde supply of target-derived trophic factor(s) together with novel, injury-induced factor(s), regulate elongating sensory neuron growth. These conditions are met after conditioning nerve injuries. Previous exposure therefore, of sensory neuron cell bodies to a lesion factor in vivo, is required for elongating growth in vitro. Hence, the LIF sequestering protein hLIF-05 failed to reduce the enhanced growth of sensory neurons from wild-type mice in vitro after preconditioning in vivo. This suggests that the responsible factor was not present at the time of the culture conditions but that cell bodies had been exposed to a retrogradely transported factor during the injury period in vivo. This factor appears absent in LIF-/- mice. Further support for a lesioninduced factor comes from other work showing that in vivoinjured segments of sciatic nerve promoted DRG axonal outgrowth in vitro far better if injured nerve segments were from wild-type and not LIF KO mice (Ekström et al., 2000). Using a different in vitro system and a longer time point at which neurite outgrowth was assessed, this latter study suggested that LIF deletion had no consequences for outgrowth after conditioning nerve lesions. After several days growth in culture, we and others (Lankford et al., 1998), find that differences between conditioned and control cultures become blurred. Because the effect of conditioning is to advance the timing and rate of neurite outgrowth into a very early postplating period, we chose to analyze growth at this time point and have demonstrated an effect of LIF deletion on neurite elongation at this time. The putative role of LIF in neurite elongation is entirely compatible with its known properties. Normally absent from the PNS, LIF ${ }^{\mathrm{mRNA}}$ expression is increased at the site of peripheral nerve injury (Sun and Zigmond, 1996), by dedifferentiating Schwann cells (Banner and Patterson, 1994). It is retrogradely transported by sensory neurons (Hendry et al., 1992; Thompson et al., 1997) and the degree of this transport regulated by nerve injury (Curtis et al., 1994). LIF accumulates in sensory neurons within the DRG (Thompson 
et al., 1997) and is capable of altering gene transcription (Sun and Zigmond, 1996).

LIF may also have a role in the inflammatory component of peripheral injury, and two studies have used LIF null mutant mice to investigate this role (Banner et al., 1998; Sugiura et al., 2000). While showing conflicting results, LIF appears proinflammatory in the injured sciatic nerve (Sugiura et al., 2000). Therefore the infiltration of inflammatory cells into the injured sciatic nerve, a process considered beneficial to regeneration, is compromised in LIF KO mice (Sugiura et al., 2000). It is a possibility that a component of the reduced peripheral nerve regeneration observed in the present study is a result of this impaired inflammatory response. On the other hand, our in vitro data would suggest that the intrinsic growth state of sensory neurons themselves is closely regulated by LIF.

\section{Gp130 cytokines have potent trophic actions in the PNS}

To date the trophic actions of gp130 cytokines has been mainly confined to regeneration within the injured motor system (Arakawa et al., 1990; Sahenk et al., 1994; Ulenkate et al., 1994; Hirota et al., 1996; Newman et al., 1996; Tham et al., 1997; Zhong et al., 1999). Our current study now provides evidence that LIF is a cornerstone for regeneration of small-diameter sensory axons. These neuropeptide-expressing neurons comprise $\sim 50 \%$ of cells within adult lumbar DRG and are likely to be nociceptors. Our data consistently points to the interaction of LIF with this population of adult sensory neurons. Hence LIF promoted neurite growth in vitro, specifically in neurons coexpressing CGRP, and exogenous LIF in vivo ameliorated axotomy-induced CGRP loss and rescued injury-associated conduction velocity decline in the slowest conduction velocity group. These data are also consistent with previous reports that LIF is retrogradely transported by small-diameter neurons in the dorsal root ganglion that express trkA and CGRP (Thompson et al., 1997).

Restoration of sensory function is an extremely desirable outcome of peripheral nerve injury. Conditioning injury has been successfully applied to promote regeneration of sensory axon branches across barriers previously considered impassable (Richardson and Issa, 1984; Richardson and Verge, 1986, 1987; Neumann and Woolf, 1999). Our study now demonstrates that the intrinsic growth status of sensory neurons may be enhanced without previous injury.

\section{REFERENCES}

Arakawa Y, Sendtner M, Thoenen H (1990) Survival affect of ciliary neurotrophic factor (CNTF) on chick embryonic motoneurons in culture: comparison with other neurotrophic factors and cytokines. J Neurosci 10:3507-3515.

Arce V, Garces A, De Bovis B, Filippi P, Henderson C, Pettmann B, deLapeyriere O (1999) Cardiotrophin-1 requires LIFRbeta to promote survival of mouse motoneurons purified my a novel technique. J Neurosci Res 55:119-126.

Banner LR, Patterson PH (1994) Major changes in the expression of the mRNAs for cholinergic differentiation factor/leukemia inhibitory factor and its receptor after injury to adult peripheral nerves and ganglia. Proc Natl Acad Sci USA 91:7109-7113.

Banner LR, Patterson PH, Allchorne A, Poole S, Woolf CJ (1998) Leukemia inhibitory factor is an anti-inflammatory and analgesic cytokine. J Neurosci 18:5456-5462.

Bomze HM, Bulsara KR, Iskandar BJ, Caroni P, Pate Skene JH (2001) Spinal axon regeneration evoked by replacing two growth cone proteins in adult neurons. Nat Neurosci 4:38-43.

Carlson RC (1983) Delayed induction of the cell body response and enhancement of regeneration following a conditioning lesion of frog peripheral nerve at $15^{\circ} \mathrm{C}$. Brain Res 279:9-18.

Cheema SS, Richards LJ, Murphy M, Bartlett PF (1994) Leukaemia Inhibitory Factor rescues motorneurons from axotomy-induced cell death. NeuroReport 5:989-992.
Chong MS, Woolf CJ, Turmaine PC, Emson PC, Anderson PN (1996) Intrinsic versus extrinsic factors in determining the regeneration of the central processes of rat dorsal root ganglion neurons: the influence of a peripheral nerve graft. J Comp Neurol 370:97-104.

Corness J, Shi TJ, Xu ZQ, Brulet P, Hokfelt T (1996) Influence of leukemia inhibitory factor on galanin/GMAP and neuropeptide Y expression in mouse primary sensory neurons after axotomy. Exp Brain Res 112:79-88.

Curtis R, Scherer SS, Somogyi R, Adryan KM, Ip NY, Zhu Y, Lindsay RM, DiStefano PS (1994) Retrograde axonal transport of LIF is increased by peripheral nerve injury: correlation with increased LIF expression in distal nerve. Neuron 12:191-204.

Diamond J, Gloster A, Kitchener P (1992a) Regulation of the sensory innervation of skin: trophic control of collateral sprouting. In: Sensory neurons: diversity, development and plasticity (Scott S, ed), pp 309322. Oxford: Oxford UP.

Diamond J, Holmes M, Coghlin M (1992b) Endogenous NGF and nerve impulses regulate the collateral sprouting of sensory axons in the skin of the adult rat. J Neurosci 12:1454-1466.

Dowsing BJ, Morrison WA, Starkey GP, Bucci T, Kilpatrick, TJ (1999) Leukemia inhibitory factor is an autocrine survival factor for Schwann cells. J Neurochem 73:96-104.

Edstrom, A, Ekström PA, Tonge D (1996) Axonal outgrowth and neuronal apoptosis in cultured adult mouse dorsal root ganglion preparations: effects of neurotrophins, of inhibition of neurotrophins actions and of prior axotomy. Neuroscience 75:1165-1174.

Ekström PA, Kerekes N, Hokfelt T (2000) Leukemia inhibitory factor null mice: unhampered in vitro outgrowth of sensory axons but reduced stimulatory potential by nerve segments. Neurosci Lett 281:107-110.

Ernsberger U, Sendtner M, Rohrer H (1989) Proliferation and differentiation of embryonic chick sympathetic neurons: effects of ciliary neurotrophic factor. Neuron 2:1275-1284.

Gadient RA, Lein P, Higgins D, Patterson PH (1998) Effect of Leukemia Inhibitory Factor (LIF) on the morphology and survival of cultured hippocampal neurons and glial cells. Brain Res 798:140-146.

Gavazzi, I, Kumar, R, McMahon SB, Cohen J (1999) Growth responses of different subpopulations of adult sensory neurons to neurotrophic factors in vitro. Eur J Neurosci 11:3405-3414.

Guo X, Metzler-Northrup J, Lein P, Rueger D, Higgins D (1997) Leukemia inhibitory factor and ciliary neurotrophic factor regulate dendritic growth in cultures of rat sympathetic neurons. Dev Brain Res 104:101-110.

Guo X, Chandrasekaran V, Lein P, Kaplan PL, Higgins D (1999) Leukemia inhibitory factor and ciliary neurotrophic factor cause dendritic retraction in cultured rat sympathetic neurons. J Neurosci 19:2113-2121.

Hendry IA, Murphy M, Hilton DJ, Nicola NA, Bartlett PA (1992) Binding and retrograde transport of leukaemia inhibitory factor by the sensory nervous system. J Neurosci 12:3427-3434.

Hirota H, Kiyama H, Kishimoto T, Taga T (1996) Accelerated nerve regeneration in mice by upregulated expression of interleukin (IL) 6 and IL-6 receptor after trauma. J Exp Med 183:2627-2634.

Hu-Tsai M, Woolf CJ, Emson PC, Winter J (1994) Neurite outgrowth and GAP-43mRNA expression in cultured adult DRG neurons: effects of NGF and prior axotomy. J Neurosci Res 39:634-645.

Kimpinski K, Campenot RB, Mearow KM (1997) Effects of neurotrophins nerve growth factor, neurotrophin-3, and brain derived neurotrophic factor (BDNF) on neurite outgrowth from adult sensory neurons in compartmented cultures. J Neurobiol 33:395-410.

Lankford KL, Waxman SG, Kocsis JD (1998) Mechanisms of enhancement of neurite regeneration in vitro following a conditioning sciatic nerve lesion. J Comp Neurol 391:11-29.

Lecomte M-J, Basseville M, Landon F, Karpov V, Fauquet M (1998) Transcriptional activation of the mouse peripherin gene by leukemia inhibitory factor: involvement of STAT proteins. J Neurochem 70:971-982.

Lindsay RM (1988) Nerve growth factors (NGF,BDNF) enhance axonal regeneration but are not required for survival of adult sensory neurons. J Neurosci 8:2394-2405.

Livesey FJ, O'Brien JA, Li M, Smith AG, Murphy LJ, Hunt SP (1997) A Schwann cell mitogen accompanying regeneration of motoneurons. Nature 390:614-618.

Martinou JC, Martinou I, Kato IC (1992) Cholinergic differentiation factor $(\mathrm{CDF} / \mathrm{LIF})$ promotes survival of isolated rat embryonic motoneurons in vitro. Neuron 8:737-744.

McQuarrie IG, Grafstein B (1973) Axon outgrowth enhanced by a previous injury. Arch Neurol 29:53-55.

McQuarrie IG, Grafstein B, Gershen MD (1977) Axonal regeneration in the rat sciatic nerve: effect of conditioning lesion and dbcAMP. Brain Res 132:443-453.

Mohiuddin, L, Fernandez, K, Tomlinson DR, Fernyhough P (1994) Nerve growth factor and neurotrophin-3 enhance neurite outgrowth and upregulate the levels of messenger RNA for growth-associated protein GAP-43 and T $\alpha 1 \alpha$-tubulin in cultured adult rat sensory neurons. Neurosci Lett 185:20-23. 
Mulderry PK (1994) Neuropeptide expression by newborn and adult rat sensory neurons in culture: effects of nerve growth factor and other neurotrophic factors. Neuroscience 59:673-688.

Murphy M, Reid K, Brown MA, Bartlett PF (1993) Involvement of LIF and nerve growth factor in the development of dorsal root ganglion neurons. Development 117:1173-1182.

Murphy M, Dutton R, Koblar S, Cheema S, Bartlett PM (1997) Cytokines which signal through the LIF receptor and their actions in the nervous system. Prog Neurobiol 52:355-378.

Neumann S, Woolf CJ (1999) Regeneration of dorsal column fibres into and beyond the lesion site following adult spinal cord injury. Neuron 23:83-91.

Newman JP, Verity AN, Hawatmeh S, Fee Jr W, Terris DJ (1996) Ciliary neurotrophic factor enhances peripheral nerve regeneration. Otolaryngol Head Neck Surg 122:399-403.

Patel TD, Jackman A, Rice FL, Kucera J, Snider WD (2000) Development of sensory neurons in the absence of NGF/TrkA signalling in vivo. Neuron 25:345-357.

Richardson PM, Issa VMK (1984) Peripheral injury enhances central regeneration of primary sensory neurons. Nature 309:791-793.

Richardson PM, Verge VMK (1986) The induction of a regenerative propensity in sensory neurons following peripheral axonal injury. J Neurocytol 15:585-594.

Richardson PM, Verge VMK (1987) Axonal regeneration in dorsal spinal roots is accelerated by peripheral axonal transection. Brain Res 411:406-408.

Sahenk Z, Seharaseyon J, Mendell JR (1994) CNTF potentiates peripheral nerve regeneration. Brain Res 655:246-250.

Sjoberg J, Kanje M (1990) Effects of repetitive conditioning crush lesion on regeneration of the rat sciatic nerve. Brain Res 530:167-169.

Smith DS, Skene JHP (1997) A transcription-dependent switch controls competence of adult neurons for distinct modes of axon growth. J Neurosci 17: $646-658$.

Sosa IJ, Reyes O, Inserni J, Kuffler DP (1998) Isolation and long-term survival of adult human sensory neurons in vitro. Neurosurgery 42:681-686.

Steward CJ, Kaspar P, Brunet LJ, Bhatt H, Gadi I, Konygen F, Abbondanzo SJ (1992) Blastocyst implantation depends upon material expression of leukemia inhibitory factor. Nature 359:76-79.
Sugiura S, Lahav R, Han J, Kou SY, Banner LR, de Pablo F, Patterson PH (2000) Leukaemia inhibitory factor is required for normal inflammatory responses to injury in peripheral and central nervous systems in vivo and is chemotactic for macrophages in vitro. Eur $\mathrm{J}$ Neurosci $12: 457-466$

Sun Y, Zigmond RE (1996) Leukaemia inhibitory factor induced in the sciatic nerve after axotomy is involved in the induction of galanin in sensory neurons. Eur J Neurosci 8:2213-2220.

Swett JE, Woolf CJ (1985) The somatotopic organisation of primary afferent terminals in the superficial laminae of the dorsal horn of the rat spinal cord. J Comp Neurol 231:66-77.

Tham S, Dowsing B, Finkelstein D, Donato R, Cheema S, Bartlett PF, Morrison WA (1997) Leukeamia inhibitory factor enhances the regeneration of transected sciatic nerve and the function of reiinervated muscle. J Neurosci Res 47:208-215.

Thier M, Marz P, Otten U, Weis J, Rose-John S (1999) Interleukin-6 (IL-6) and its soluble receptor support survival of sensory neurons. J Neurosci Res 55:411-422.

Thompson SWN, Vernallis AE, Heath JK, Priestley JV (1997) LIF is retrogradely transported by a distinct population of adult rat sensory neurons: co-localization with trkA and other neurochemical markers. Eur J Neurosci 9:1244-1251.

Thompson SWN, Priestley JV, Southall A (1998) gp130 cytokines, LIF and IL-6, induce neuropeptide expression in intact adult rat sensory neurons in vivo: time course, specificity and comparison with sciatic nerve axotomy. Neuroscience 84:1247-1255.

Ulenkate HJ, Kaal EC, Gispen WH, Jennekens FG (1994) Ciliary neurotrophic factor improves muscle fibre reinnervation after facial nerve crush in young rats. Acta Neuropathol 88:558-564.

Vernallis AB, Hudson KR, Heath JK (1997) An antagonist for the LIF receptor inhibits LIF, cardiotrophin-1, ciliary neurotrophic factor and oncostatin-M. J Biol Chem 272:26947-26952.

Wang KH, Brose K, Arnott D, Kidd T, Goodman CS, Henzel W, Tessier-Lavigne M (1999) Biochemical purification of a mammalian Slit protein as a positive regulator of sensory axon elongation and branching. Cell 96:771-784

Zhong, J, Dietzel ID, Wahle P, Kopf M, Heumann R (1999) Sensory impairments and delayed regeneration of sensory axons in interleukin6-deficient mice. J Neurosci 19:4305-4313. 